\title{
COMPARISON OF DIFFERENT METHODS FOR MEASURING IMMUNOGLOBULIN CONTENT IN CALF SERUM
}

\author{
Mette Bagger and Lis Eriksen \\ Internal Medicine, Department of Clinical Studies, The Royal Veterinary and Agricultural University, \\ Dyrlægevej 88, 1970 Frederiksberg C, Denmark
}

Objectives. The correlation between an IgG1 ELISA and different methods for immunoglobulin and serum protein determination was examined in calves 1-77 days of age to compare methods to establish failure of passive transfer of immunoglobulins.

Materials and Methods. Blood samples were taken from 92 calves and age, sex, general condition and weight (weighing or thorax measure) were recorded. In serum total protein concentration was measured by Biuret's method and refractometer (Atago, Bie and Berntsen A/S). Immunoglobulin contents was masured by the semiquantitative serum glutaraldehyde test (Tennant et al. 1979, 174, 848-853, a commercial whole blood IgG test (Quick Test Calf Whole Blood IgG K ${ }^{\mathrm{TM}}$, Midland BioProducts Corporation) and a direct sandwich $\mathrm{IgG}_{1}$ ELISA developed in our laboratory.

Results. Significant correlations was found between serum $\mathrm{IgG}_{1}$ concentration and serum protein concentration measured by refractometer or Biuret and between the two methods of protein determination. Tests positive $(>10 \mathrm{~g} / \mathrm{lgG})$ with the commercial test kit had significant higher IgG1 concentration $(29.79 \mathrm{~g} / \mathrm{l})$ than negative test $(9.75 \mathrm{~g} / \mathrm{l})$. Significant correlation was also demonstrated between $\mathrm{IgG}_{1}$ and the glutaraldehyde coagulation test.

The table below shows the sensitivity, specificity, positive (posPV) and negative (negPV) predictive value and \% correct classified calves (CCC) with the commercial test kit (CTK), the glutaraldehyde test (GAT) and refractometer (REFR) in relation to an $\operatorname{IgG}_{1}>10 \mathrm{~g} / \mathrm{l}=$ no failure of passive transfer and $\mathrm{IgG}_{1}<10 \mathrm{~g} / \mathrm{l}=$ failure of passive transfer.

\begin{tabular}{llllll}
\hline Method & sensitivity & specificity & posPV & negPV & \%CCC \\
\hline $\begin{array}{l}\text { Commercial } \\
\text { test kit }\end{array}$ & 0.70 & 0.92 & 0.88 & 0.79 & 81.57 \\
$\begin{array}{l}\text { GAT time } \\
10 \mathrm{~min}\end{array}$ & 0.35 & 0.02 & 0.24 & 0.03 & 17.36 \\
$15 \mathrm{~min}$ & 0.58 & 1 & 1 & 0.73 & 80.59 \\
$20 \mathrm{~min}$ & 0.58 & 0 & 0.24 & 0 & 27.13 \\
REFR & & & & & \\
$40 \mathrm{~g} / 1$ & 0.05 & 1 & 0 & 0.84 & 55.49 \\
$50 \mathrm{~g} / 1$ & 0.54 & 0.90 & 0.73 & 0.69 & 72.85 \\
$55 \mathrm{~g} / 1$ & 0.95 & 0.69 & 0.61 & 0.94 & 81.83 \\
$60 \mathrm{~g} / 1$ & 1 & 0.45 & & 1 & 70.63 \\
\hline
\end{tabular}

Conclusions. With ELISA IgG1 as reference significant correlations were demonstrated between the various methods used. In calves from 1-77 days of age a serum protein concentration of $55 \mathrm{~g} / \mathrm{l} \mathrm{mea-}$ sured by refractometer correctly classified $81.63 \%$ of the calves as having serum IgG1 concentrations below $10 \mathrm{~g} / \mathrm{l}$. Therefore, the simple refractometer method is recommended for field use to measure failure of colostrum uptake in individual calves. 